\title{
Epidemiological Insights of Foot and Mouth Disease Virus Infection among Cattle and Buffaloes in Sharkia Governorate, Egypt
}

\author{
Ahmed Orabi $^{1 *}$, Shimaa M.G. Mansour ${ }^{1}$, Ayman M. Megahed ${ }^{2}$ and Ayman A. Saleh ${ }^{3}$ \\ ${ }^{1}$ Virology Department, Faculty of Veterinary Medicine, Zagazig University, 44511, Egypt \\ ${ }^{2}$ Veterinary Public Health Department, Faculty of Veterinary Medicine, Zagazig University, \\ 44511, Egypt \\ ${ }^{3}$ Animal Wealth Development Department, Faculty of Veterinary Medicine, Zagazig University, \\ 44511, Egypt
}

Article History: Received: 4/4/2017 Received in revised form: 10/5/2017 Accepted: 12/6/2017

\begin{abstract}
Foot-and-mouth disease (FMD) is endemic in Egypt and in most parts of Africa causing huge economic losses. Control of FMD using vaccination requires information on the occurrence of various FMDV serotypes. This study aimed to determine the prevalence of FMDV serotypes in Sharkia Governorate, Egypt. A total number of 643 different samples, within ten different localities, were collected from both cattle and buffaloes $(n=283)$ of different, age, sex, immune status against FMD, and health status. Field samples $(n=360)$ have been screened for FMDV by RT-PCR using universal primers and were further subtyped using serotype-specific primers. Additionally, serum samples $(\mathrm{n}=283)$ have been analyzed by applying FMDV serotype-specific antibody ELISA. The RT-PCR screening revealed that a total number of 39/283 (13.8\%), 61/283 $(21.6 \%)$ and $17 / 38(44.7 \%)$ animals were positive for FMDV serotype O, A and SAT2, respectively. While, by ELISA, neutralizing antibodies directed against FMDV serotype O, A, and SAT2, were found in 177/283 (62.5\%), 171/283 (60.4\%) and 27/38 (71.1\%) serum samples, respectively. These results indicated the endemic status of the FMDV serotypes O, A and SAT2 in Sharkia Governorate despite routine FMD vaccination programs. Although many variations of disease prevalence were recorded between animals of different, age, sex and immune and health status but it was obvious that FMD was more prominent and prevalent in buffaloes $(47.1 \%)$ than in cattle $(34.1 \%)$. Therefore, control efforts should focus on reducing the circulation of FMDV among susceptible livestock with special attention towards water buffaloes. Continuous surveillance, at molecular and immunological levels, of FMDV serotypes is needed for the effectiveness of any adopted control strategy targeting FMD including vaccination.
\end{abstract}

Keywords: Prevalence, FMDV, Cattle, Buffaloes, Egypt.

\section{Introduction}

Foot-and-mouth disease (FMD) is a highly contagious viral disease affecting both domestic and wild cloven-hoofed animals [1]. The FMD virus (FMDV) belongs to the genus Aphthovirus, the family Picornaviridae and the order Picornavirales [2]. The virus is highly mutable because its genome is composed of a linear, positive single-stranded RNA molecule with a quasispecies nature allowing the continuous evolution of new variants $[3,4]$. There are seven immunological distinct FMDV serotypes with multiple subtypes within each serotype $(\mathrm{O}, \mathrm{A}, \mathrm{C}$, Asia 1, South African Territories (SAT) 1, SAT 2, and SAT 3). With the exception of serotype C,
FMDV serotypes are still circulating worldwide (Africa, Asia, west Eurasia, and South America) [5,6]. There is no antigenic relationship between the different FMDV serotypes, therefore, the cross-protection does not exist totally. Moreover, in many cases, the cross-protection between different subtypes of the same serotype fails to be induced [7]. Consequently, continuous updating of data regarding to the field circulating topotypes is necessary for appropriate vaccine manufacture and disease control $[8,9]$.

In many developing countries including Egypt, FMD is endemic and considered as a major transboundary disease that causes great 
limitations on sales and exports of livestock and livestock products $[10,11]$. Serotype O was considered the predominant serotype in Egypt because it induced all outbreaks between 1964 and 2005 excluding an outbreak in 1972 that was caused by serotype A [12,13]. In 2006, Sharkia and many Egyptian Governorates were stroked by severe FMD outbreaks caused by serotype A $[12,14]$. Vaccination programs depending on locally produced bivalent vaccines, against both serotypes $\mathrm{A}$ and $\mathrm{O}$, were applied however severe FMD outbreaks existed in February 2012. Sharkia and Gharbia were the first Egyptian Governorates in which these outbreaks were recognized. Large numbers of cattle and water buffaloes showed severe clinical signs of FMD and a high mortality rate (up to 50\%) particularly in young animals as a result of FMDV-induced myocarditis. An exotic FMDV serotype (SAT2) was the primary cause of the 2012- FMD epidemic in Egypt [15,16]. During 2012-2014, the three FMDV serotypes, O, A, and SAT2 were detected in many outbreaks among cattle and water buffaloes in Egypt [6].

The control of FMD is depending largely on the disease epidemiological data which in turn affected by many factors including the role of different susceptible hosts in disease transmissibility and persistency. In addition, the incursion of exotic viral strains in FMD endemic areas including Egypt has a great impact on the epidemiological map of the disease [10]. This study was carried out to generate data regarding the prevalence of FMDV serotypes in Sharkia Governorate, Egypt. For this reason, the different FMDV serotypes and their specific antibodies were tested in clinically sick and apparently healthy cattle and buffalos in different localities across Sharkia Governorate, Egypt.

\section{Material and methods}

\section{Area and animals under investigation}

The study was conducted in Sharkia Governorate, Egypt during 2008-2015. Samples were collected randomly from both sick or apparently healthy cattle and buffaloes of different, ages (from 7 days to 6 years), sexes, and immune status (vaccinated and non- vaccinated animals). The selected animals ( $\mathrm{n}=$ 283) were reared in villages/houses and farms that reported FMD outbreaks within ten cities/centers in Sharkia Governorate. A total number of 196 houses/farms (cattle $=56$, buffalos $=99$ and integrated rearing system of cattle and buffalos together $=41$ ) were investigated (Figure 1 Upper panel). These localities had active FMD outbreaks 2 weeks to 8 months before sampling.

\section{Clinical specimens}

Clinical specimens were collected from animals with typical signs and lesions of FMD (Figure 1 Lower panel) and from apparently healthy animals during sampling. At sampling time, the owners of the farms/animals have been questioned in regard to their FMD vaccine practice.

A total number of 360 field samples were collected from cattle and buffaloes. These samples comprised of 154 samples (88 mouth epithelia, 19 vesicular fluids, and 47 oral swabs) from cattle and buffaloes suspected of being infected with FMDV and 206 samples (87 oropharyngeal (OP) swabs, 82 fecal and 37 milk samples) from apparently healthy animals. In addition, 283 blood samples were collected from cattle and buffaloes, of which, 126 were collected from 33 sick and 93 apparently healthy cattle. The remaining 157 blood samples were collected from 88 sick and 69 apparently healthy buffalos. The samples were used for preparation of sera to detect antibodies against FMDV serotypes $(\mathrm{O}, \mathrm{A}$ and SAT2).

\section{Reverse transcription and Polymerase chain reaction}

Total RNA was extracted from the collected filed samples using the GeneJET RNA Purification Kit (Thermo scientific, EU) according to the manufacturer's recommendations. The extracted RNA was examined firstly by RT-PCR using universal primers $1 \mathrm{~F} / 1 \mathrm{R}$ generating $328 \mathrm{bp}$ product regardless of the serotype [17]. The RT-PCR was performed using Verso ${ }^{\mathrm{TM}}$ One Step RTPCR Kit (Thermo scientific, EU). The thermal profile was started at $50^{\circ} \mathrm{C}$ for $30 \mathrm{~min}$ for reverse transcription; then $\mathrm{PCR}$ activation at 
$95^{\circ} \mathrm{C}$ for $15 \mathrm{~min}$; followed by 35 cycles at $94^{\circ} \mathrm{C}$ for $30 \mathrm{sec}, 55^{\circ} \mathrm{C}$ for $30 \mathrm{sec}$, and $72^{\circ} \mathrm{Cfor}$ 90 sec. Finally, the PCR reaction was completed at $72^{\circ} \mathrm{C}$ for $10 \mathrm{~min}$ and the PCR products were then analyzed by gel electrophoresis. For identifying the serotype in each of the FMDV PCR positive samples, another RT-PCR was performed using serotype-specific primers for serotypes $\mathrm{O}, \mathrm{A}$ and SAT2 as previously described [17,18].

\section{Virus isolation on BHK-21 cells}

Positive serotype-specific RT-PCR samples for serotypes O, A and SAT2 were prepared for the isolation of FMDV according to the directions of OIE [19]. The prepared samples $(150 \mu \mathrm{L})$ were added in a triplicate manner to pre-formed monolayers of baby hamster kidney-21 (BHK-21) cells grown in 24-well plates. The plates were incubated at $37^{\circ} \mathrm{C}$ for 1 $\mathrm{h}$, followed by change of media and continued incubation at $37^{\circ} \mathrm{C}$ for 4 days with daily observation for the development of cytopathic effect (CPE). The harvest of positive isolates was further tested by the serotype-specific RTPCR for the presence of FMDV. Aliquots of infected cell lysate of each sample were processed and used for coating ELISA plates [20] to be used for the detection of serotype specific antibodies.

\section{Serum antibody assay}

The collected serum samples were checked for specific antibodies against O, A, and SAT2 serotypes of FMDV in enzyme-linked immunosorbent assay (ELISA) microtiter plates by the Solid Phase Blocking (SPB) indirect ELISA [20]. Each serum sample was run in duplicates; the tests were carried out on a screening basis at a dilution of 1/16. As controls, antigen, known positive and negative sera were included in each ELISA plate. Optical density (OD) values were determined using ELISA reader (Behring EL311) at a wave length of $492 \mathrm{~nm}$. The formula is as follows, where $\mathrm{OD}=$ optical density:

$$
\text { Value }=\frac{\text { OD sample }-O D \text { negative }}{\text { OD positive }-O D \text { negative }}
$$

\section{Statistical analysis}

Prevalence of FMDV determined as the proportion of the samples in which infection was detected by RT-PCR. The statistical analysis for RT-PCR results was done using Chi-Square test in SPSS 11.0 software (SPSS Inc., Chicago, IL, USA). The WinPepi software, Version 11.65 [21] was used for calculation of prevalence and $95 \%$ confidence interval $(95 \% \mathrm{CI})$. The seropositivity rates were determined by dividing the total number of positive sera by the total number of tested samples and were expressed as a percentage.

\section{Results}

\section{Clinical signs}

The clinical signs during the FMD epidemic among buffaloes included fever, anorexia, vesicles and ulcers in lips (Figure 1 Lower panel A), tongue, gum with excessive salivation, and lameness. Same lesions were also observed in cattle in addition to ulcers in nostrils (Figure 1 Lower panel B). Some young animals exhibited diarrhea and sudden deaths without previous clinical signs, especially buffalo calves less than 1 month old. Others were clinically examined and showed a cardiac arrhythmia followed by respiratory distress and grunting just before death. At sampling time, mortality rates of $21 \%$ and $18 \%$ were recorded among sick cattle and buffalos, respectively.

\section{Molecular detection of FMDV serotypes by RT-PCR}

The RT-PCR targeting 5' UTR, using universal primers, revealed 117 FMDV infected animals (Table 1) with an overall prevalence of $41.3 \% \quad(117 / 283,95 \%$ CI $35.6 \%-47 \%)$. This percentage varied according to species, health status, locality, age, sex and immune status (Table 1). The FMDV detection rates in cattle and buffalos were $34.1 \%$ and $47.1 \%$, respectively. FMDV was detected in $76 \%$ of sick and $15.4 \%$ of apparently healthy animals. There was a significant variation between the tested samples that were collected from diseased and apparently healthy animals. In sick animals, the FMDV was detected in $22 / 33$ cattle and $70 / 88$ buffaloes with the percentages of $66.7 \%$ 
and 79.5\%, respectively. However, the apparently healthy animals that tested positive for FMDV were 21/93 cattle and 4/69 buffaloes with the percentages of $22.6 \%$ and $5.8 \%$, respectively.

According to the locality of sampling, the highest positivity rate of FMDV infection $(83.3 \%)$ came from EL-Hosayneya, followed by Kafr Sakr (57.1\%), Minet Elkamh (56.5\%), Zagazig (48.1\%) and Abu Kabier (45.5\%), The lowest detection rate was observed in
Mashtul assuq (4.8\%). The virus detection rate was significantly higher in animals older than one year than in younger animals $(48.5 \%$ versus $24.7 \%$, respectively. Regarding to gender, the virus detection rate in females (43.8\%) was insignificantly higher than in males $(32.2 \%)$. The non-vaccinated animals showed a higher detection rate of FMD $(46.1 \%)$ than that of vaccinated ones $(39.2 \%)$, however, this difference was non-significant.

Table 1: Epidemiological data for FMDV infection in cattle and buffalos in Sharkia Governorate, Egypt

\begin{tabular}{|c|c|c|c|c|}
\hline Variable & $\begin{array}{c}\text { Sample } \\
\text { collected, No. } \\
(\%) \\
\end{array}$ & $\begin{array}{c}\text { FMDV-positive } \\
\text { samples, No. } \\
(\%)\end{array}$ & p value & $95 \% \mathrm{CI}$ \\
\hline Species & & & 0.027 & \\
\hline Cattle & $126(44.5 \%)$ & $43(34.1 \%)$ & & $25.9-43.1$ \\
\hline Buffalo & $157(55.5 \%)$ & $74(47.1 \%)$ & & $39.1-55.3$ \\
\hline Health status & & & $<0.001$ & \\
\hline Healthy & $162(57.2 \%)$ & $25(15.4 \%)$ & & $10.2-21.9$ \\
\hline Sick & $121(42.8 \%)$ & $92(76.0 \%)$ & & $67.4-83.3$ \\
\hline Sample type & & & $<0.001$ & \\
\hline $\begin{array}{l}\text { Oral samples (mouth epithelium, } \\
\text { vesicular fluid, oral swab) }\end{array}$ & $154(42.8 \%)$ & $116(75.3 \%)$ & & $67.7-81.9$ \\
\hline OP (oropharyngeal) & $87(24.2 \%)$ & $25(28.7 \%)$ & & $19.5-39.4$ \\
\hline Feces & $82(22.8 \%)$ & $0(0)$ & & 0 \\
\hline Milk & $37(10.3 \%)$ & $1(2.7 \%)$ & & $0-14.2$ \\
\hline Localities & & & $<0.001$ & \\
\hline Zagazig & $81(28.6 \%)$ & $39(48.1 \%)$ & & $36.9-59.5$ \\
\hline Minet Elkamh & $46(16.3 \%)$ & $26(56.5 \%)$ & & $41.1-71.1$ \\
\hline Abu-Hamad & $35(12.4 \%)$ & $11(31.4 \%)$ & & $16.9-49.3$ \\
\hline Fakus & $15(5.3 \%)$ & $2(13.3 \%)$ & & $1.7-40.5$ \\
\hline Belbis & $23(8.1 \%)$ & $7(30.4 \%)$ & & $13.2-52.9$ \\
\hline Hihya & $20(7.1 \%)$ & $8(40 \%)$ & & $19.1-63.9$ \\
\hline Abu Kabier & $22(7.8 \%)$ & $10(45.5 \%)$ & & $24.4-67.8$ \\
\hline Kafr Sakr & $14(4.9 \%)$ & $8(57.1 \%)$ & & $28.9-82.3$ \\
\hline El-Hosayneya & $6(2.1 \%)$ & $5(83.3 \%)$ & & $35.9-99.6$ \\
\hline Mashtul assuq & $21(7.4 \%)$ & $1(4.8 \%)$ & & $0.1-23.8$ \\
\hline Age (year) & & & $<0.001$ & \\
\hline$\leq 1$ year & $85(30.0 \%)$ & $21(24.7 \%)$ & & $15.9-35.3$ \\
\hline$>1$ year & $198(70.0 \%)$ & $96(48.5 \%)$ & & 41.3-55.7 \\
\hline Sex & & & 0.1089 & \\
\hline Male & $59(20.8 \%)$ & $19(32.2 \%)$ & & $20.6-45.6$ \\
\hline Female & $224(79.2 \%)$ & $98(43.8 \%)$ & & $37.2-50.5$ \\
\hline Immune status & & & 0.2733 & \\
\hline Vaccinated & $194(68.6 \%)$ & $76(39.2 \%)$ & & $32.3-46.4$ \\
\hline Non vaccinated & $89(31.4 \%)$ & $41(46.1 \%)$ & & 33.4-56.9 \\
\hline
\end{tabular}


Table 2: Typing of FMDV in sick and apparently healthy cattle and buffalos

\begin{tabular}{|c|c|c|c|c|c|c|}
\hline \multirow[t]{2}{*}{ Species } & \multirow[t]{2}{*}{ Status } & \multirow{2}{*}{$\begin{array}{c}\text { Total No of } \\
\text { samples }\end{array}$} & \multicolumn{4}{|c|}{ No of positive (\%) } \\
\hline & & & $5^{`} \mathrm{UTR}$ & $\mathbf{O}$ & $\mathbf{A}$ & SAT2* \\
\hline \multirow[t]{2}{*}{ Cattle } & Sick & 33 & $22(66.7)$ & $5(15.2)$ & $14(42.4)$ & $3(9.1)$ \\
\hline & Apparently healthy & 93 & $21(22.6)$ & $18(19.4)$ & $2(2.2)$ & $1(1.1)$ \\
\hline \multirow[t]{2}{*}{ Buffalo } & Sick & 88 & $70(79.5)$ & $14(15.9)$ & $44(50.0)$ & $12(13.6)$ \\
\hline & Apparently healthy & 69 & $4(5.8)$ & $2(2.9)$ & $1(1.4)$ & $1(1.4)$ \\
\hline Total & & 283 & $117(41.3)$ & $39(13.8)$ & $61(21.6)$ & $17(6.0)$ \\
\hline
\end{tabular}

* Total number of samples collected after incursion of SAT2 in Egypt was 38. Number of positive SAT2 in those samples was $17 / 38$ with a percentage of $44.7 \%$.

Typing of FMDV-positive samples using serotype-specific primers revealed FMDV serotypes O, A and SAT2 in 39 (13.8\%), 61 $(21.6 \%)$ and $17(6 \%)$ animals, respectively (Table 2). Moreover, the results indicated that all FMDV-positive samples were of the SAT2 serotype (14/17) during outbreaks of 2012 and 2013 with the percentage of $83.2 \%$. The amplification products were identified at the expected positions of $328 \mathrm{bp}$ for FMDV and $1,301,863-866$ or 880 bp for O, A or SAT2, respectively (data not shown).

\section{Sero-prevalence}

Using SPB indirect ELISA method, specific antibodies against FMDV serotypes $\mathrm{O}, \mathrm{A}$ and SAT2 were detected. Specific FMDV serotype $\mathrm{O}$ antibodies were detected in 88 $(69.8 \%)$ cattle and $89(56.7 \%)$ buffalo serum samples, respectively. Whereas, FMDV serotype A neutralizing antibodies were detected in $77(61.1 \%)$ and $94(59.9 \%)$ sera collected from cattle and buffalos, respectively. The specific antibodies against FMDV serotype SAT2 were detected in 20 $(83.3 \%)$ cattle and $7(50 \%)$ buffalo serum samples. The sero-positivity of the FMDV serotypes O, A and SAT2 appeared also variable according to other four factors; health status, age, sex, and immune status (Figure 2).

There were great variations in the seropositivity of the FMDV serotypes $\mathrm{O}$, A and SAT2 in the different localities. For serotype A specific antibodies, the percentages of seropositivity ranged from $25 \%$ in Fakus and Kafr Sakr to $100 \%$ in El-Hosayneya. The highest seropositive results $(83.3 \%)$ against FMDV serotype $\mathrm{O}$ were detected in cattle sera collected from Abu Kabier, while the lowest results were $18.8 \%$ in Abu-Hamad. In buffalo sera, the highest antibody prevalence (100\%) for both FMDV serotype $\mathrm{A}$ and $\mathrm{O}$ was recorded in Belbis. No antibodies against serotype A were detected in sera collected from Fakus. The SAT2 specific antibodies was detected in, one $(33.3 \%)$ serum sample from cattle and buffaloes in El-Hosayneya, and in $19(90.5 \%)$ serum samples from cattle and 6 $(54.5 \%)$ serum samples from buffaloes in Mashtul assuq and Minet Elkamh, respectively (Fig. 3).

\section{Discussion}

Since its first detection in 1964 among Egyptian livestock [22], FMD is being the most frequent endemic viral disease affecting the Egyptian animal industry causing drastic economic losses. Both FMDV serotypes $\mathrm{O}$ and A were the only serotypes incriminated in the disease endemicity in Egypt until 2011 $[12,15,23]$. In February 2012, a different serotype, SAT2, was introduced causing an extensive FMD outbreak among Egyptian animals $[16,24]$. Up to date, several FMD outbreaks are still stroking the livestock in Egypt in spite of routine massive vaccination. This raises the question whether these outbreaks are caused by the same serotypes or by new one/s. Thereby, identification of circulating serotypes is essential and will aid in the proper vaccine choice and consequently reduce disease losses. Thus, at the immunological and molecular levels among clinically infected and apparently healthy Egyptian cattle and buffaloes in Sharkia Governorate were examined for the presence of FMDV infection.

It has been reported that the infection in African buffalo with FMDV is almost subclinical [25]. In this study, with the exception of one lesion (erosions or ulcers on the 
nostrils, Figure 2B) which was observed only in many infected cattle, all clinically infected animals including buffaloes showed typical signs of FMD [26]. This assumes that water buffaloes are more susceptible to FMDV infection than African ones. Moreover, it was shown that water buffaloes are more resistant to FMDV infection and showed less signs and lesions than cattle [27]. However, in this study a total number of $70(79.5 \%)$ buffaloes that tested positive for FMD showed moderate to severe typical clinical signs of the disease. In addition, the overall mortality rate among infected buffaloes $(18 \%)$ was close to that of cattle $(21 \%)$. This could be attributed to the adaptation of circulating FMDV serotypes to both animal species (cattle and buffalo) producing severe clinical signs [28,29].
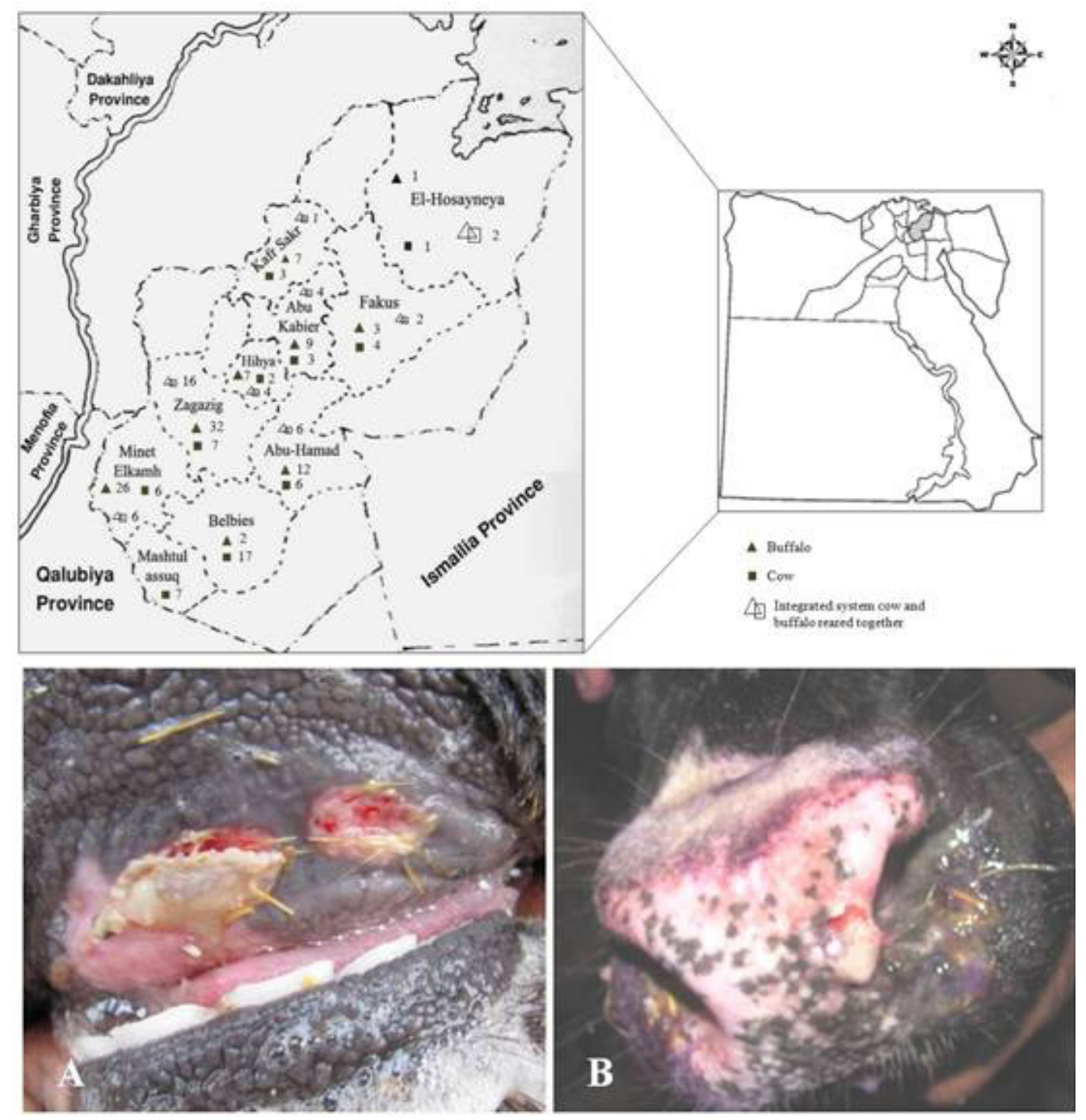

Figure 1: Sites and animals investigated for FMDV infection in Sharkia Governorate, Egypt. Map of Egypt showing Sharkia Governorate (grey). The samples were collected from ten cities/centers within Sharkia Governorate, Egypt. Figure shows the number of investigated cattle- and buffalo- houses/farms per center (Upper panel). Clinical manifestation of animal suspected to be affected by FMDV, Sharkia Governorate. A) Blanching of epithelium after vesicle rupture on the upper lip of a buffalo. B) Erosion in the nostril of a cow (Lower panel). 


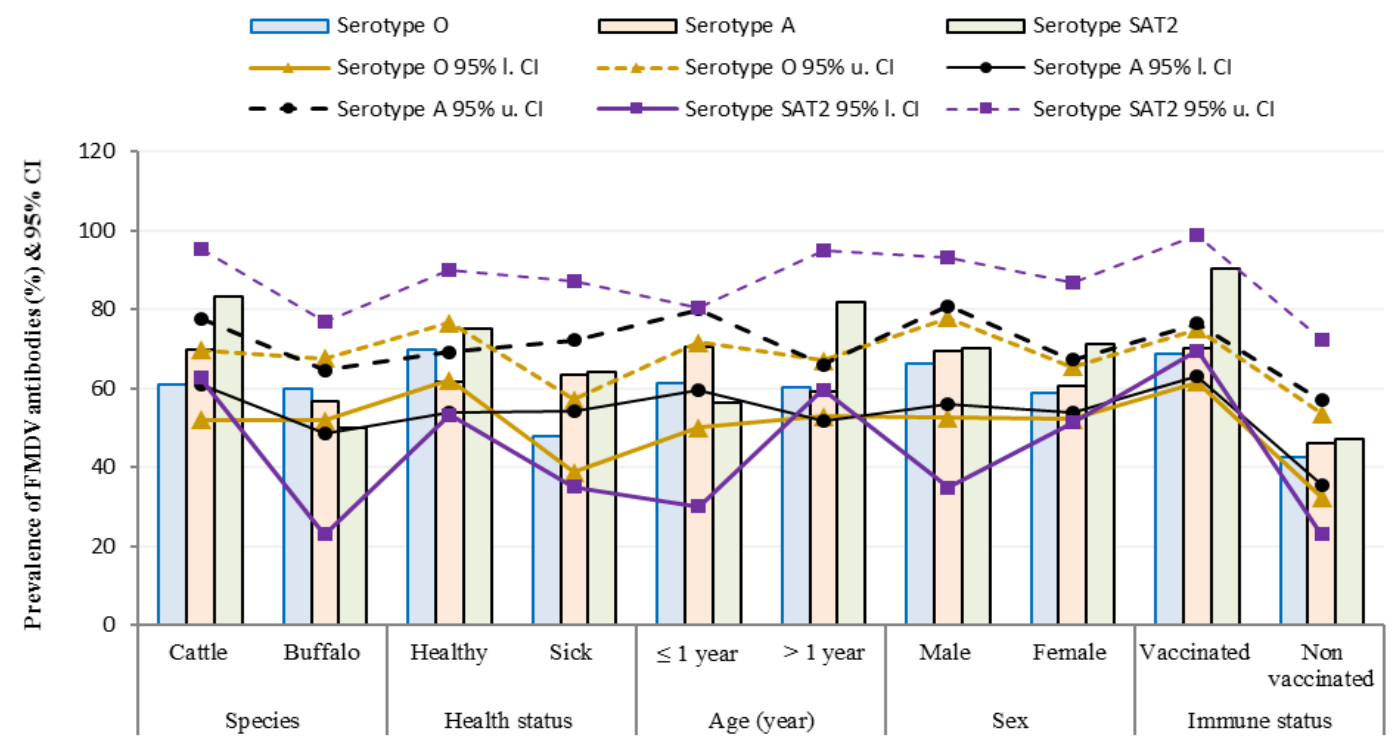

Figure 2: Sero-prevalence of specific antibodies against FMDV serotypes, O, A and SAT2 in serum samples of cattle and buffaloes according to animal species, health status, age, sex, and immune status using indirect SPB ELISA. The Figure displays the sero-positivity percentages (columns) and $95 \%$ confidence interval; Lower confidence interval (l. CI) and upper confidence interval (u. CI) (lines).

The molecular detection of FMDV among cattle and buffaloes using specific RT-PCR revealed a relatively high rate $(41.3 \%)$ of active virus infection. The quasispecies nature of FMDV [3] along with inefficient routine vaccination may be implicated in such high infection rate. It was also reported that FMDV may circulate undetectable among vaccinated herds [30]. Further studies showed that experimental infection in non-vaccinated buffalos and cattle with FMDV induced more prominent clinical signs in buffaloes compared to cattle [28]. In our study, contrary to the apparently healthy buffaloes which showed lower percent $(5.8 \%)$ of FMDV positive animals than apparently healthy cattle $(22.6 \%)$, a higher proportion $(79.5 \%)$ of FMDV positive animals were detected among symptomatic buffaloes compared to symptomatic cattle $(66.7 \%)$ (Table 2$)$. These results confirm that a higher percent of Egyptian water buffaloes rather than cattle escaped from vaccination or improperly vaccinated and became highly adapted to the circulating FMDV strains [29]. Most samples that tested positive for FMDV using RT-PCR were the oral samples $(75.3 \%)$ and then the oropharyngeal (OP) swabs $(28.7 \%)$ (Table 1). This indicates that most studied FMD infected animals were in the acute state of the disease whereas other animals were sub-clinically or persistently infected [13]. Only one milk sample $(2.7 \%)$ tested positive for the presence of FMDV (Table 1). A possible explanation is that all the examined milk samples were collected from apparently healthy animals and there was no evidence for the persistence of FMDV in mammary tissue at 28 dpi [31]. In addition, all fecal samples were collected from apparently healthy animals and tested negative for FMDV, although some OP swabs from the same animals were positive. This assumes that the fecal sample is not ideal for the detection and consequently the surveillance of FMDV especially among sub-clinically or persistently infected cattle or buffaloes. The percent of FMD infected animals above 1 year age $(48.5 \%)$ was nearly the double of those less than 1 year age $(24.7 \%)$ (Table 1). This may be attributed to colostral antibodies which protect animals up to 6 months of age which in turn decrease the rate of FMDV infection among calves of less than 1 year old [13]. 
However, most deaths were among animals less than 1 year age (data not shown). This could be attributed to that naïve calves develop more prominent clinical FMD signs and lesions than older animals including cardiac affections which are considered the main cause of high mortalities among younger animals [32]. This also highlights the importance of proper vaccination of the dams to protect their young calves.

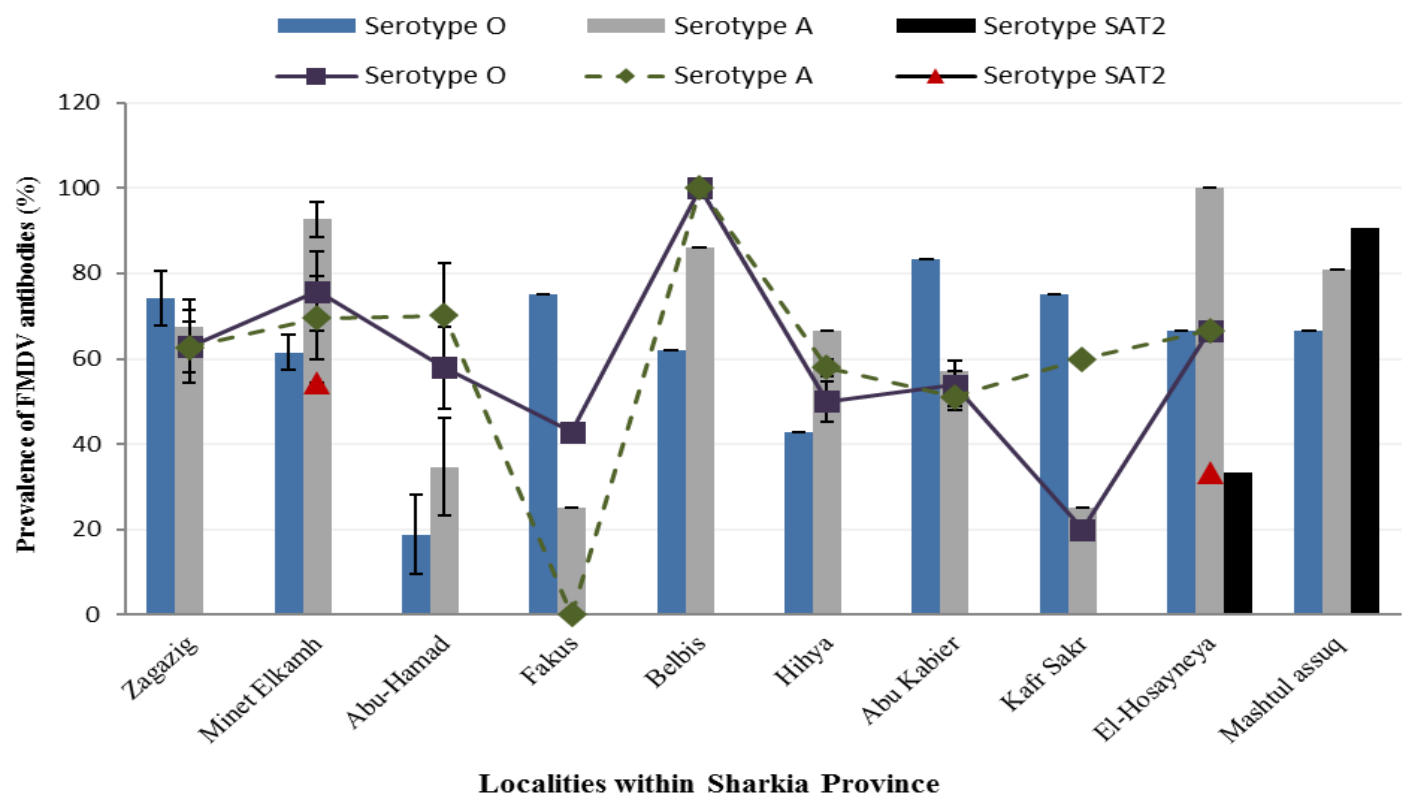

Figure 3: Sero-prevalence of specific antibodies against FMDV serotypes, A, $O$ and SAT2 in serum samples of cattle (columns) and buffaloes (lines) in different localities within Sharkia Governorate using indirect SPB ELISA. The Figure displays the mean sero-positivity percentages \pm standard error (Bars).

The three FMDV serotypes, O, A, and SAT2 were identified in the examined samples using RT-PCR and indirect SPB ELISA (for antibody detection). By RT-PCR, our results revealed variable detection rates, ranged from $4.8 \%$ to $83.3 \%$ among investigated localities (Table 1). In the same accordance, ELISA results showed antibodies against the three FMDV serotypes, O, A and SAT2, ranged from $18.8-100 \%$ and $0-100 \%$ in sera collected from cattle and buffaloes, respectively. These variations may be attributed to sample size and site, sampling time, age and sex and immune and health status of investigated animals particularly considering the intensive movement of animals and the lack of good hygiene and quarantine precautions especially during outbreaks [29]. By ELISA, the results demonstrated that the overall sero-prevalence of antibodies against FMDV serotype $\mathrm{O}$ and $\mathrm{A}$ was $69.8 \%$ and $56.7 \%$ in the examined cattle and buffalo populations, respectively. Specific FMDV serotype A neutralizing antibodies of $61.1 \%$ and $59.9 \%$ were detected in cattle and buffalo sera, respectively. On the contrary, lower prevalence against the both serotypes was reported by detecting specific antibodies against FMDV serotypes $\mathrm{A}$ and $\mathrm{O}$ in $17.5 \%$ and $4.17 \%$ of apparently healthy bovine sera [33]. Those variations may be attributed to the difference in the method of ELISA used. The specific antibodies against FMDV serotype SAT2 were detected in $83.3 \%$ cattle and $50 \%$ buffalo serum samples. Similarly, Wekesa and his colleagues recorded the presence of SAT2 neutralizing antibodies in $51.96 \%$ of African buffaloes [34]. In this study, $68.6 \%$ of all questioned owners vaccinated their animals. Of those, $11 \%$ were vaccinated their animals on regular manner twice per year, whereas the majority of the owners vaccinated only the newly introduced animals. They administered the vaccine only once without any additional 
booster vaccination. Besides, the overall seroprevalence against FMDV serotype $\mathrm{O}$, A, and SAT 2, was $62.5 \% \quad(177 / 283), \quad 60.4 \%$ $(171 / 283)$ and $71.1 \%(27 / 38)$. Therefore, this does not essentially mean that the animals have acquired the immunity by becoming infected with each serotype. It may be suggested that those animals have been vaccinated with bi-or multi-valent vaccines, either after they have had an infection or the vaccine strain has not matched with the circulating one [35].

\section{Conclusion}

In conclusion, the three serotypes of FMDV; O, A, and SAT 2 are constantly circulating among cattle and buffaloes in different localities within Sharkia Governorate, Egypt. For an effective and realizable FMD control program in Sharkia Governorate, Egypt, we suggest ensuring that mass vaccination covers all cattle and buffaloes twice annually at least, with special and district attention to animals in villages (house rearing). Those vaccinations should be administered along with the already individual performed vaccinations to provide a continuous high level of herd immunity.

\section{Conflict of interest}

The authors declare no conflicts of interest.

\section{Acknowledgments}

The authors would like to thank the Molecular Biology and Biotechnology Research Unit, Animal Wealth Development Department, Faculty of Veterinary Medicine, Zagazig University.

\section{References}

[1] Davies, G. (2002): Foot and mouth disease. Res Vet Sci, 73(3): 195-199.

[2] ICTV (2015): Virus Taxonomy: 2015 Release. EC 47, London, UK, July 2015 Available at: http://wwwictvonlineorg/virustaxonomyas p.

[3] Domingo, E.; Sheldon, J. and Perales, C. (2012): Viral quasispecies evolution. Microbiol Mol Biol Rev, 76(2): 159-216.
[4] Domingo, E.; Escarmis, C.; Martinez, M.A.; Martinez-Salas, E. and Mateu, M.G. (1992): Foot-and-mouth disease virus populations are quasispecies. Curr Top Microbiol Immunol, 176: 33-47.

[5] Mason, P.W.; Pacheco, J.M.; Zhao, Q.Z. and Knowles, N.J. (2003): Comparisons of the complete genomes of Asian, African and European isolates of a recent foot-andmouth disease virus type $\mathrm{O}$ pandemic strain (PanAsia). J Gen Virol, 84(6): 15831593.

[6] FAO (2015): Global Foot-and-Mouth Disease Situation, Food and Agriculture Organization of the United Nations, January 2015.

[7] Jamal, S.M.; Ferrari, G.; Ahmed, S.; Normann, P. and Belsham, G.J. (2011): Molecular characterization of serotype Asia-1 foot-and-mouth disease viruses in Pakistan and Afghanistan; emergence of a new genetic Group and evidence for a novel recombinant virus. Infect Genet Evol, 11(8): 2049-2062.

[8] Jamal, S.M.; Shah, S.I.; Ali, Q.; Mehmood, A.; Afzal, M.; Afzal, M. and Dekker, A. (2014): Proper quality control of formulated foot-and-mouth disease vaccines in countries with prophylactic vaccination is necessary. Transbound Emerg Dis, 61(6): 483-489.

[9] Biswal, J.K.; Jena, S.; Mohapatra, J.K.; Bisht, P. and Pattnaik, B. (2014): Detection of antibodies specific for foot-and-mouth disease virus infection using indirect ELISA based on recombinant nonstructural protein 2B. Arch Virol, 159(7): 1641-1650.

[10] Rweyemamu, M.; Roeder, P.; Mackay, D.; Sumption, K.; Brownlie, J.; Leforban, Y.; Valarcher, J. F.; Knowles, N. J. and Saraiva, V. (2008): Epidemiological patterns of foot-andmouth disease worldwide. Transbound Emerg Dis, 55(1): 57-72.

[11] Paton, D.J.; Sinclair, M. and Rodriguez, R. (2010): Qualitative assessment of the commodity risk for spread of foot-andmouth disease associated with 
international trade in deboned beef. Transbound Emerg Dis, 57(3): 115-134.

[12] Knowles, N.J.; Wadsworth, J.; Reid, S.M.; Swabey, K.G.; El-Kholy, A.A.; Abd El-Rahman, A. O.; Soliman, H. M.; Ebert, K.; Ferris, N. P.; Hutchings, G. H.; Statham, R. J.; King, D. P. and Paton, D. J. (2007): Foot-and-mouth disease virus serotype A in Egypt. Emerg Infect Dis, 13: $1593-1596$.

[13] OIE (2012): Manual of diagnostic tests and vaccines for terrestrial animals 2012. Paris:World Organisation for Animal Health.

[14] Ghoneim, N.H.; Abdel-Karim, A.K.; ElShehawy, L. and Abdel-Moein, K.A. (2010): Foot and mouth disease in animals in Sharkia governorate - Egypt. Transbound Emerg Dis, 57(1-2): 19-21.

[15] Ahmed, H.A., Salem, S.A.; Habashi, A.R.; Arafa, A.A.; Aggour, M.G.; Salem, G. H.; Gaber, A. S.; Selem, O.; Abdelkader, S. H.; Knowles, N. J.; Madi, M.; Valdazo-Gonzalez, B.; Wadsworth, J.; Hutchings, G. H.; Mioulet, V.; Hammond, J. M. and King, D. P. (2012): Emergence of foot-and-mouth disease virus SAT 2 in Egypt during 2012. Transbound Emerg Dis, 59(6): 476-481.

[16] Kandeil, A.; El-Shesheny, R.; Kayali, G.; Moatasim, Y.; Bagato, O.; Darwish, M.; Gaffar, A.; Younes, A.; Farag, T.; Kutkat, M. A. and Ali, M. A. (2013): Characterization of the recent outbreak of foot-and-mouth disease virus serotype SAT2 in Egypt. Arch Virol, 158(3): 619627.

[17] Reid, S.M.; Ferris, N.P.; Hutchings, G.H.; Samuel, A.R. and Knowles, N.J. (2000): Primary diagnosis of foot-and-mouth disease by reverse transcription polymerase chain reaction. J Virol Methods, 89(1): 167-176.

[18] Bastos, A.D.; Haydon, D.T.; Sangare, O.; Boshoff, C.I.; Edrich, J.L. and Thomson, G.R. (2003): The implications of virus diversity within the SAT 2 serotype for control of foot-and-mouth disease in sub-
Saharan Africa. J Gen Virol, 84(6): 1595-1606.

[19] OIE (2000): Annual Status 2000. Foot and mouth disease, Chapter 2.1.1 in manual of standards for diagnostic tests and vaccine, 4th Ed., Paris. 77-92.

[20] Chénard, G.; Miedema, K.; Moonen, P.; Schrijver, R.S. and Dekker, A. (2003): A solid-phase blocking ELISA for detection of type $\mathrm{O}$ foot-and-mouth disease virus antibodies suitable for mass serology. J Virol Methods, 107(1): 8998.

[21] Abramson, J.H. (2011): WINPEPI updated: computer programs for epidemiologists, and their teaching potential. Epidemiol Perspect Innov, 8(1): 1 .

[22] Moussa, A.A.M.; Daoud, A.; Hussein, K.; Fahmy, F.; El-Kilany, S. and ElShehawy, L. (1979): Prevalence of FMD in Egypt. 14th Arab Veterinary Congress, 14: 39-50.

[23] Knowles, N.J.; Nazem Shirazi, M.H.; Wadsworth, J.; Swabey, K.G.; Stirling, J.M.; Statham, R. J.; Li, Y.; Hutchings, G. H.; Ferris, N. P.; Parlak, U.; Ozyoruk, F.; Sumption, K. J.; King, D. P. and Paton, D. J. (2009): Recent spread of a new strain (A-Iran-05) of foot-andmouth disease virus type $\mathrm{A}$ in the Middle East. Transbound Emerg Dis, 56(5): 157169.

[24] El-Shehawy, L.I.; Abu-Elnaga, H.I.; Rizk, S.A.; Abd El-Kreem, A.S.; Mohamed, A.A. and Fawzy, H. G. (2014): Molecular differentiation and phylogenetic analysis of the Egyptian foot-and-mouth disease virus SAT2. Arch Virol, 159(3): 437-443.

[25] Thomson, G.R.; Vosloo, W. and Bastos A.D. (2003): Foot and mouth disease in wildlife. Virus Res, 91: 145-161.

[26] Meyer, R.F. and Knudsen, R.C. (2001): Foot-and-mouth disease: a review of the virus and the symptoms. $\mathbf{J}$ Environ Health, 64(4): 21-23. 
[27] Alexandrov, T.; Stefanov, D.; Kamenov, P.; Miteva, A.; Khomenko, S; Sumption, K.; Meyer-Gerbaulet, H. and Depner, K. (2013): Surveillance of foot-and-mouth disease (FMD) in susceptible wildlife and domestic ungulates in Southeast of Bulgaria following a FMD case in wild boar. Vet Microbiol, 166(1): 84-90.

[28] Madhanmohan, M.; Yuvaraj, S.; Nagendrakumar, S.B.; Srinivasan, V.A.; Gubbins, S; Paton, D.J. and Parida, S. (2014): Transmission of foot-and-mouth disease virus from experimentally infected Indian buffalo (Bubalus bubalis) to in-contact naive and vaccinated Indian buffalo and cattle. Vaccine, 32(39): 5125-5130.

[29] Constable, P.D.; Hinchcliff, K.W.; Done, S. and Gruenberg, W. (2017): Veterinary Medicine 11th Edition: A textbook of the diseases of cattle, horses, sheep, pigs and goats - two-volume set. Elsevier Health sciences, Philadelphia, PA USA.

[30] Kitching, R.P. (2002): Identification of foot and mouth disease virus carrier and subclinically infected animals and differentiation from vaccinated animals. Rev Sci Tech, 21(3): 531-538.

[31] Reid, S.M.; Parida, S.; King, D.P.; Hutchings, G.H., Shaw, A.E., Ferris, N.
P.; Zhang, Z.; Hillerton, J. E. and Paton, D. J. (2006): Utility of automated realtime RT-PCR for the detection of footand-mouth disease virus excreted in milk. Vet Res, 37(1): 121-132.

[32] Geering, W.A. and Lubroth, J. (2002): Preparation of Foot-and-Mouth Disease Contingency Plans. Food and Agriculture Organization, Rome: 39-57.

[33] Martinez, S.C. and Quintero, M. (1998): Use of liquid phase ELISA kit for detection of antibodies against food-andmouth disease virus (FMDV) in Colombia International Atomic Energy Agency, Vienna (Austria); Food and Agriculture Organization of the United Nations, Rome (Italy): 29: 554-555.

[34] Wekesa, S.N.; Sangula, A.K.; Belsham, G.J., Tjornehoj, K.; Muwanika, V.B.; Gakuya, F.; Mijele, D. and Siegismund, H. R. (2015): Characterisation of recent foot-and-mouth disease viruses from African buffalo (Syncerus caffer) and cattle in Kenya is consistent with independent virus populations. BMC Vet Res, 11(1): 17.

[35] Klein, J. (2009): Understanding the molecular epidemiology of foot-andmouth-disease virus. Infect Genet Evol, 9(2): 153-161. 


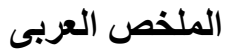

$$
\begin{aligned}
& \text { رؤي ويائية لعدوى فيروس مرض الحمى القلاعية بين الأبقار والجاموس في محافظة الثرقية بمصر }
\end{aligned}
$$

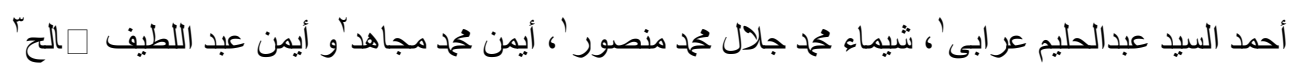

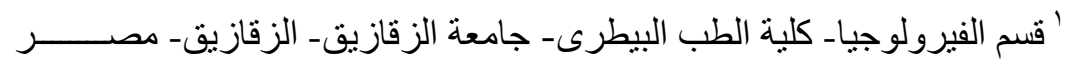

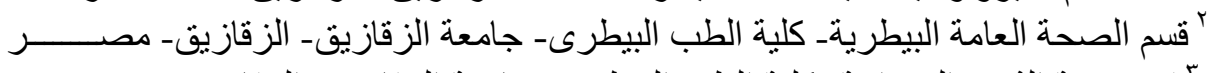

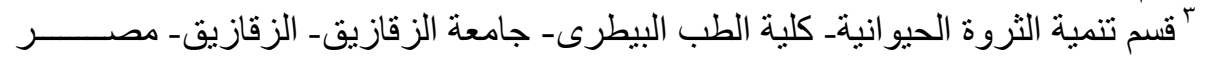

يعد مرض الحمي القلاعية من الامراض المتوطنة في جمهورية مصر العربية وكذلك في معظم أجزاء قارة افريقيا

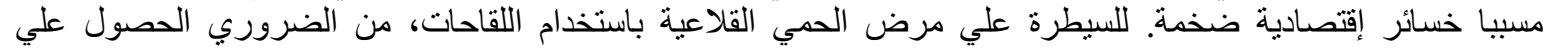

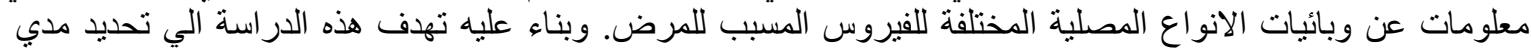

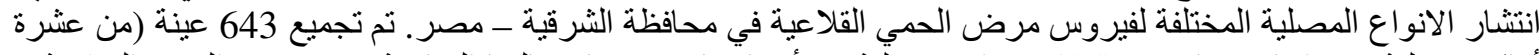

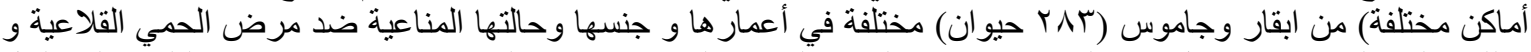

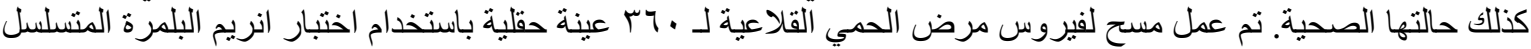

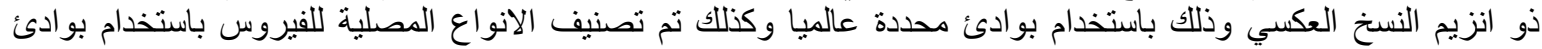

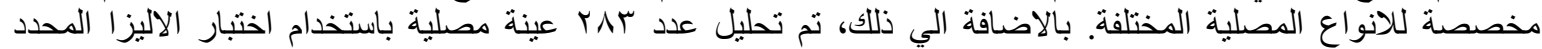

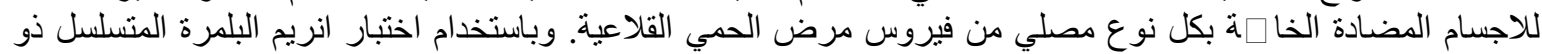

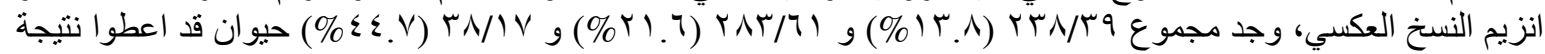
ايجابية لفيروس مرض الحئ الحمي القلاعية من النوع المصلي O و A و

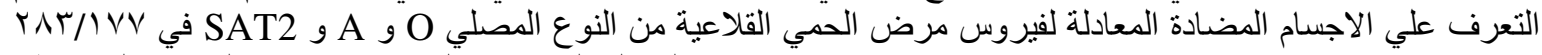

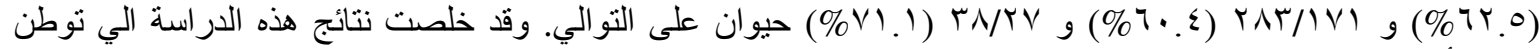

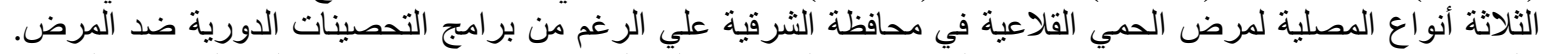

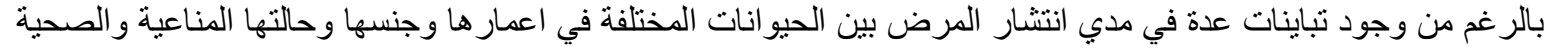

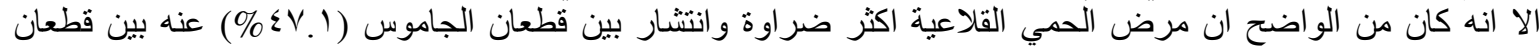

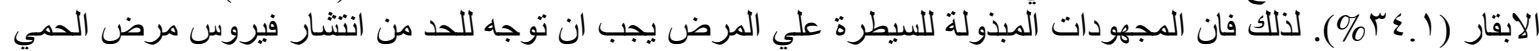

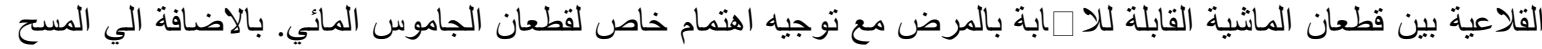

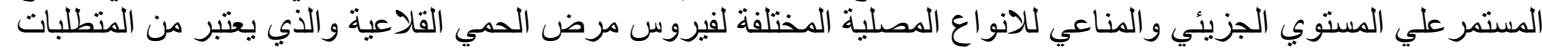

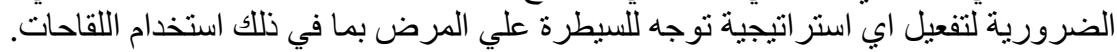

